\title{
Osteoprotective Properties of RNA-Containing Drug Osteochondrin $S$ on the Model of Insufficiency of Sex Hormones in Rats
}

\author{
Propiedades Osteoprotectoras del Fármaco que Contiene ARN de Osteocondrina \\ $S$ sobre un Modelo de Insuficiencia de Hormonas Sexuales en Ratas
}

\author{
Zarina Shulgau, Shynggys Sergazy, Tatyana Krivoruchko, Nuriya Kenzhebayeva, Bayan Sagindykova, Alexandr Gulyayev
}

SHULGAU, Z.; SERGAZY, S.; KRIVORUCHKO, T.; KENZHEBAYEVA, N.; SAGINDYKOVA, B. \& GULYAYEV, A. Osteoprotective properties of RNA-containing drug Osteochondrin S on the model of insufficiency of sex hormones in rats. Int. $J$. Morphol., 35(4):1233-1238, 2017.

SUMMARY: The aim of the study was to evaluate the osteoprotective properties of RNA-containing drug Osteochondrin S on rats with experimental model of osteoporosis. Osteochondrin S contains yeast RNA and RNA of connective tissue of cattle. In order to model osteoporosis in rats bilateral ovariectomy was used. Rats were divided into 3 groups: 1 - ovariectomized rats receiving Osteochondrin $\mathrm{S} ; 2$ - ovariectomized rats receiving saline; 3 - sham-ovariectomized rats. Rats in group 1 received Osteochondrin S, Group 2 - physiological saline three times a week for 12 weeks. Based on morphological data and on the results of densitometry, Osteochondrin S prevents a decrease in bone density, i.e. exhibits osteoprotective properties. Under the condition of lack of sex hormones in rats Osteochondrin $\mathrm{S}$ reduces reactive oxygen species in blood plasma and limits the degree of decrease in antioxidant capacity of blood plasma.

KEY WORDS: Ovariectomy; Osteoporosis; Osteochondrin S; RNA extracts.

\section{INTRODUCTION}

In recent years, a large amount of data on the use of RNA-containing drugs under various pathological conditions has been accumulated. RNA-containing drugs can accelerate tissue regeneration upon damage, change the course of the inflammatory process, stimulate subpopulations of lymphocytes, enhance phagocytosis of macrophages and influence the body's responses to tumors and allografts (Afjeh et al., 2013; Dogini et al., 2014; Shu et al., 2014; Zeliadt, 2014). These effects of RNA-containing substances can be useful in correcting of age-associated conditions (Ni et al., 2011; Masuda et al., 2013). The main mass of RNA preparations consists of various variants of micro RNA (mRNA), obtained by RNA interference methods and constituting a promising class of regulatory molecules, however, RNA preparations "native organopreparations" retain a certain value among RNA-containing substances. As a typical example, biologically active substances known as a ribonucleic acid / ribonucleotide extract (RN preparations), derivatives of connective tissue of animals and yeast (Schroeder et al., 1989; Rainsford, 1996). Previously, similar RNA-containing substances were widely used in the complex therapy of various inflammatory syndromes, including arthritis (Stommel et al., 2015).

The object of this study was the RNA-containing preparation Osteochondrin $\mathrm{S}$, which, in addition to the yeast RNA, contains RNA of bovine cattle from intervertebral discs, cartilage, synovial fluid, placenta. This biologically active substance, known as the ribonucleic acid extract, the derivative of the connective tissue of animals and yeast (Schroeder et al.; Rainsford). Osteochondrin $\mathrm{S}$ is a unique natural product that, due to its therapeutic effect obtained under empirical, long-term use by physicians in patients with osteoarthritis, attracted the attention of researchers who found this biological product was able to inhibit the activity of osteoclasts (Cantley et al., 2013). Early experimental work

Republican State Enterprise "National Center for Biotechnology" under the Science Committee of Ministry of Education and Science of the Republic of Kazakhstan. Complete address: 13/5, Kurgalzhynskoye road, Astana, 010000, Kazakhstan.

The research results presented in the article are made under the grant "Evaluation of the safety and efficacy of RNA-containing biologically active substances with geroprotective potential", funded by Science Committee of the Ministry of Education and Science. 
suggested the ability of this substance to stimulate the synthesis of glycosaminoglycans and collagen and to accelerate the regeneration of bone tissue in rats (Babiichuk \& Belous, 1969). In spite of the fact that Osteochondrin $\mathrm{S}$ was used in European countries as a medicine and now as a complementary medicine, the description of the basic pharmacological mechanism of Osteochondrin S is absent and its effect on bone tissue is not known in detail.

The search for substances with osteoprotective activity is relevant in the context of the prevalence of osteoporosis syndrome. According to statistics, the average life expectancy of women is steadily growing and more than one-third of her life is in the period of peri- and postmenopause, i.e. in conditions of age-related changes in homeostasis, accompanied by a profound restructuring of the hormonal profile and psychophysiological reactions to these changes. In this regard, more attention should be paid to adequate treatment of menopausal problems in more than $70 \%$ of women in this period of life. Women with estrogen deficiency caused by menopause, in addition to psychoemotional symptoms and an increase of cardiovascular diseases, develop bone resorption and osteoporosis (Pérez-López, 2004; Siris et al., 2014; Matsushita \& Wakatsuki, 2015; Eftekhar-Sadat et al., 2016).

The aim of the study was to assess the osteoprotective properties of the RNA-containing preparation Osteochondrin $\mathrm{S}$ on the model of osteoporosis in rats caused by insufficiency of sex hormones.

\section{MATERIAL AND METHOD}

Osteochondrin $\mathrm{S}$ is a natural ribonucleotide extract of bovine-derived connective tissues (from accredited BSE-free sources) and yeast.

The study was approved by the Local Ethics Committee of the National Center for Biotechnology (Protocol No. 1 of June 18, 2015). The experiments were carried out on 18 outbred female rats weighing 200-240 g. The animals were obtained from the vivarium of the National Center for Biotechnology. During the experiment the animals were housed in boxes of polypropylene (three each) and kept under controlled environmental conditions of temperature $\left(22 \pm 2{ }^{\circ} \mathrm{C}\right)$ and lighting (12-hour cycle of light and 12 hours dark). Animals were in the standard conditions of the vivarium on a normal diet and free access to water and food (ad libitum). Control and experimental animals were in similar conditions and had the same initial mean mass.
To reproduce osteoporosis, an ovariectomy model was used, since it is known that hypoestrogenemia is accompanied by the development of osteoporosis (Haddad et al., 2015; Jung. et al., 2016). The removal of the ovaries was carried out according to a conventional technique (Vasconcellos et al., 2004; Haddad et al.). Under aseptic conditions, rats underwent a laparotomy under anesthesia - the skin was dissected along the midline of the abdomen, the muscles were bluntly extended, revealing the internal sexual organs of the female rats. The ovary was untied with ligatures from the uterus horns and blood vessels and excised. The wound was layer-by-layer closed and the treatment of the operating field with antiseptics was performed. Rats, which underwent laparotomy and had sutured wounds, formed a group of sham-ovariectomized animals.

The animals were divided into 3 study groups:

Group 1 (6 rats) - study group seven days after ovariectomy, animals were injected Osteochondrin $\mathrm{S}$ intraperitoneally in an amount of $0.2 \mathrm{ml}$ per rat 3 times a week. The total duration of the introductions is 12 weeks;

Group 2 (6 rats) - control group, received an equivoluminal amount $(0.2 \mathrm{ml}$ per rat) of a sterile physiological solution 3 times a week intraperitoneally, starting from the 7 th day after ovariectomy. The total duration of the introductions is 12 weeks;

Group 3 (6 rats) - sham-ovariectomized rats, received an equivoluminal amount $(0.2 \mathrm{ml}$ per rat) of a sterile physiological solution 3 times a week intraperitoneally, starting from the 7 th day after laparotomy. The total duration of the introductions is 12 weeks.

To assess the osteoprotective properties, bone tissue density was measured 3 months after the procedure of ovariectomy. The density of bone tissue was studied on an Ivis Spectrum CT, PerkinElmer, USA.

The femur was taken for histological examination to perform a comparative morphological characterization in the control group of animals, and after treatment with the RNA preparation Osteochondrin S. For morphological study, the femur was fixed in a $10 \%$ neutral formalin solution. After fixation histological tissue was embedded in wax-paraffin. Subsequently, paraffin sections with a thickness of 4-5 microns were made, which were stained with hematoxylin and eosin for a survey study, and an evaluation of the nature of the morphological processes in different groups of the experiment.

Study of the oxidative status in blood plasma of rats was done by FRAS 4 instrument (Evolvo s.r.l., Italy) using d- 
ROMs Test sets (shows the amount of ROS) and PAT Test (characterizes the total antioxidant activity of blood plasma).

The experiments were carried out in accordance with the "Rules of the European Convention for the Protection of Vertebrates used for experimental and other scientific purposes". The protocol for studying the osteoprotective properties of the Osteochondrin S RNA preparation was approved by the Local Ethical Commission of the National Center for Biotechnology.

\section{RESULTS AND DISCUSSION}

To reproduce osteoporosis in rats, a two-way ovariectomy model was used, since it is known that insufficiency of sex hormones is accompanied by the development of osteoporosis (Pérez-López; Haddad et al.; Jung et al.).

In sham-ovariectomized rats, bone tissue is represented by a compact bone (cortical layer) and trabecular (spongy) bone. The external (periosteal) and internal (endocostal) bone surfaces are lined with bone-forming cells that form the periosteum and endosteum. Morphological composition of bone tissue is represented by cellular elements, intercellular substance (matrix), mineral components. Cellular elements of bone tissue are determined: osteoblasts, osteocytes, osteoclasts (Fig. 1).

In the animals of the control group, osteoporotic changes in the bones of the skeleton were histologically confirmed in all rats after ovariectomy. In the spongy substance, thinning of the latticed network of trabeculae and microperforation of bone plates were observed; the trabeculae network was partially interrupted in places as a result of the disappearance of horizontal trabeculae. In addition, micro fractures of bone trabeculae were noted in individual histological specimens. In vessels of medium and small caliber there is arterial, venous plethora and moderate proliferation of the endothelium. Cellular elements of bone tissue are defined with a decrease in osteoblasts and osteocytes, an increase in osteoclasts (Fig. 2).

Rats develop impaired vascular endothelial function, including the microcirculatory bed of bone tissue, as evidenced by the moderate proliferation of endothelium with endothelial dysfunction. The blood filling of capillaries in the bone tissue significantly worsens, which leads to the development of generalized osteoporosis, accompanied by thinning of the bone trabeculae and the appearance of microfractures in them.

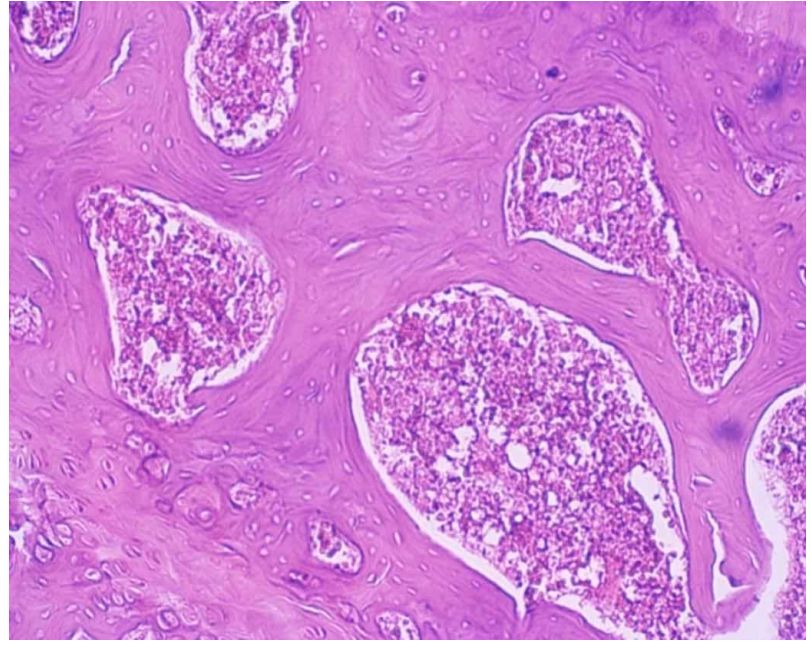

Fig. 1. Bone tissue of sham-ovariectomized rats. The ratio of compact and trabecular layers is not violated.

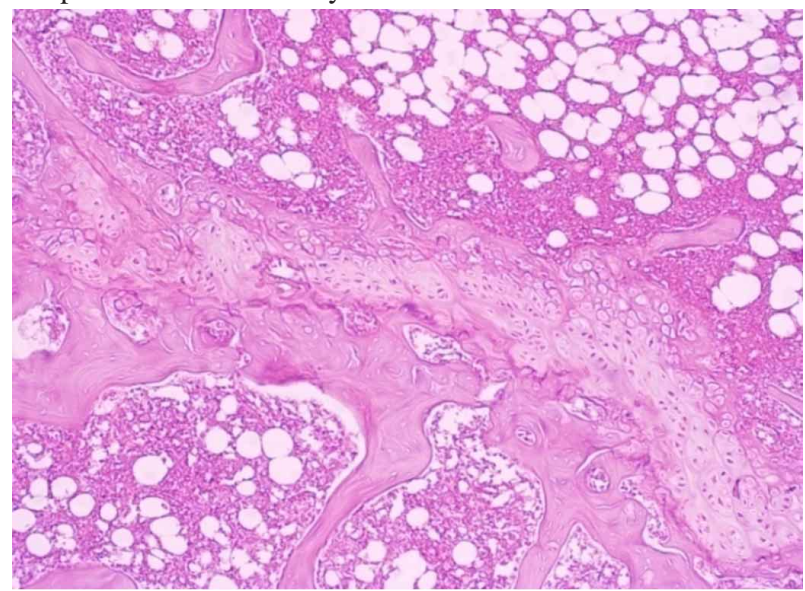

Fig. 2. Bone tissue of animals with ovariectomy. The compact layer is thin, thin trabecular structures. Prevalent spongy substance with fatty vacuoles and cellular components.

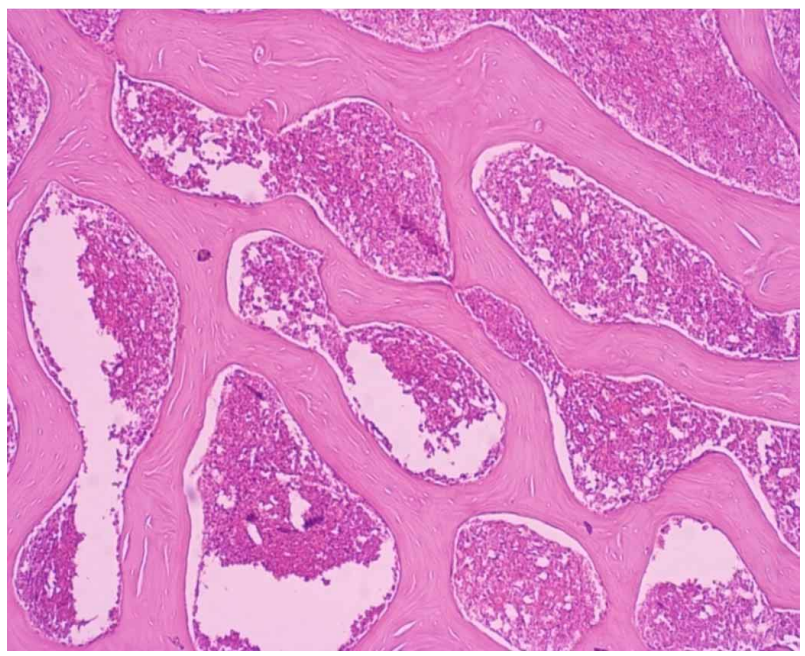

Fig. 3. Bony tissue of animals with ovariectomy treated with Osteochondrin $\mathrm{S}$. The ratio of the compact and trabecular layer is not disturbed. 
Thus, after ovariectomy in female rats, obvious signs of systemic osteoporotic changes in the bones of the skeleton were developed, characterized by thinning of the bone trabeculae, leading to a decrease in their mechanical strength and, as a consequence, the appearance of micro-fractures.

In the group of animals with ovariectomy receiving the RNA preparation Osteochondrin S, the ratio of compact and trabecular layers is not violated. Bone tissue is represented by a cortical layer and a spongy substance. The periosteal and endocostal bone surfaces are represented by bone-forming cells. Bone tissue consists of cellular elements, matrix and mineral components. The main cellular elements of bone tissue are determined - osteoblasts, osteocytes and osteoclasts. The predominantly normal ratio of bone tissue to spongy substance is revealed -1: 1 (Fig. 3).

Based on the obtained pathomorphological data, it can be concluded that the use of Osteochondrin S prevents the destruction of bone tissue.

To further evaluate the osteoprotective properties, bone density was measured 3 months after the ovariectomy procedure. The density of bone tissue was studied on an Ivis Spectrum CT, PerkinElmer, USA.

Table I presents the measurements of bone density of animals with the model of osteoporosis and animals administered Osteochondrin S.

The results obtained during the determination of bone density fully confirm the data of the morphological study. In animals with ovariectomy, the density of bone tissue decreases in comparison with sham-ovariectomized rats.
In the group of animals treated with Osteochondrin $\mathrm{S}$, the bone density is higher than in the untreated control group, the bone density index reaches values in animals without ovariectomy. It can be argued that the drug Osteochondrin $\mathrm{S}$ is able to prevent the development of osteoporosis in animals with ovariectomy.

Ovariectomy in rats, like estrogen deficiency in women, provokes an increase in the processes of lipid peroxidation, and is one of the causes of oxidative stress (López-Grueso et al., 2014; Machi et al., 2016). The results of the study of the antioxidant effects of the Osteochondrin $S$ under the conditions of the model of osteoporosis caused by the insufficiency of sex hormones in rats are presented in Table II.

D-ROMs test shows the concentration of active oxygen species (AOS) in the blood plasma. Against the background of insufficiency of sex hormones in rats, the concentration of AOS increases in the control group. RNAcontaining drug Osteochondrin S promotes decrease in AOS.

PAT test allows to measure the antioxidant potential of blood plasma. In rats with osteoporosis caused by the insufficiency of sex hormones, the antioxidant potential decreases compared to the untreated rats in all study groups. Introduction Osteochondrin S somewhat limits the degree of reduction in the antioxidant potential of the blood plasma.

Thus, the data of morphology and densitometry prove that Osteochondrin S prevents the destruction of bone tissue in animals against the background of a lack of sex hormones, which may be due to the limitation of increasing the level of free radicals and reducing the level of antioxidants in the

Table I. Effect of Osteochondrin S on bone density in rats with a model of osteoporosis caused by insufficiency of sex hormones in rats.

\begin{tabular}{lcccc}
\hline Test parameter & & Sham-ovariec tomized rats & Control rats & Osteochondrin S \\
\hline $\begin{array}{l}\text { Density of bone } \\
\text { hounsfield }\end{array}$ & tissue, & $1554 \pm 37$ & $1288 \pm 11^{*}$ & $1651 \pm 86^{+}$ \\
\hline
\end{tabular}

$*<0,05$ Compare to the values of sham-ovariectomized rats; $+<0,05$ Compare to the values in the animals of the control group

Table II. Antioxidant effects of Osteochondrin S in rats with a model of osteoporosis caused by insufficiency of sex hormones in rats.

\begin{tabular}{lccc}
\hline Test parameter & Sham-ovarie ctomized rats & Control rats & Osteochondrin S \\
\hline $\begin{array}{l}\text { D-ROMs test, } \mathrm{U} \text { CARR } \\
\left(1 \mathrm{U} \text { CARR }=0.08 \mathrm{mg} / 100 \mathrm{ml} \mathrm{H}_{2} \mathrm{O}_{2}\right)\end{array}$ & $286 \pm 13$ & $425 \pm 43^{*}$ & $331 \pm 37^{+}$ \\
$\begin{array}{l}\text { PAT test, } \mathrm{U} \text { Cor } \\
(1 \mathrm{U} \text { Cor }=1,4 \mu \mathrm{M} / \mathrm{L} \text { ascorbic acid) }\end{array}$ & $2636 \pm 259$ & $1956 \pm 112^{*}$ & $2135 \pm 126$ \\
\hline
\end{tabular}

$*<0,05$ Compare to the values of sham-ovariectomized rats; $+<0,05$ Compare to the values in the animals of the control group. 
blood plasma of rats after ovariectomy. The data obtained by us agree with the results of Cantley et al. who found that Osteochondrin $\mathrm{S}$ is able to inhibit the activity of osteoclasts derived from human peripheral blood mononuclear cells, by using the colony stimulating factor and the nuclear factor $\mathrm{kB}$ receptor activator (RANK ligand). Both results serve as the basis for the assumption that the Osteochondrin $\mathrm{S}$ substance has a potential for osteoprotective activity.

\section{CONCLUSION}

Results of morphology and densitometry confirm that Osteochondrin $\mathrm{S}$ has a pronounced osteoprotective activity, preventing the destruction of bone tissue in animals with insufficiency of sex hormones. Osteochondrin $\mathrm{S}$ is able to limit the development of oxidative stress in animals with ovariectomy.

\section{ACKNOWLEDGMENTS}

The results of the research presented in the article were carried out within the framework of the grant "Evaluation of the safety and effectiveness of RNAcontaining biologically active substances with geroprotective potential", funded by the Science Committee of the Ministry of Education and Science of the Republic of Kazakhstan.

SHULGAU, Z.; SERGAZY, S.; KRIVORUCHKO, T.; KENZHEBAYEVA, N.; SAGINDYKOVA, B. \& GULYAYEV, A. Propiedades osteoprotectoras del fármaco que contiene ARN Osteocondrina S sobre un modelo de insuficiencia de hormonas sexuales en ratas. Int. J. Morphol., 35(4):1233-1238, 2017.

RESUMEN: El objetivo de este estudio fue evaluar las propiedades osteoprotectoras del fármaco que contiene ARN Osteocondrina $\mathrm{S}$ en ratas, como modelo experimental de osteoporosis. La Osteocondrina S contiene ARN de levadura y ARN de tejido conectivo de bovinos. Para modelar la osteoporosis en ratas se utilizó ovariectomía bilateral. Las ratas se dividieron en 3 grupos: grupo 1, ratas ovariectomizadas que recibieron Osteocondrin S; grupo 2, ratas ovariectomizadas recibieron solución salina; grupo 3 - ratas ovariectomizadas simuladas. Las ratas del grupo 1 recibieron Osteocondrina $S$, el grupo 2 solución de suero fisiológico tres veces por semana durante 12 semanas. En base a los datos morfológicos y los resultados de la densitometría, Osteocondrina S evita una disminución de la densidad ósea, es decir, exhibe propiedades osteoprotectoras. Ante la falta de hormonas sexuales en ratas, Osteocondrina $S$ reduce las especies reactivas de oxígeno en el plasma sanguíneo y limita el grado de disminución de la capacidad antioxidante del plasma sanguíneo.
PALABRAS CLAVE: Ovariectomía ; Osteoporosis; Osteocondrina S; Extractos de ARN.

\section{REFERENCES}

Afjeh, S. S. A. \& Ghaderian, S. M. H. The role of microRNAs in cardiovascular disease. Int. J. Mol. Cell. Med., 2(2):50-7, 2013.

Babiichuk, G. A. \& Belous, A. M. Effect of a preparation of exogenous homologous RNA and hydrocortisone on the level of collagen and glucosaminoglycans in rat bone regenerate preparation. Bull. Eksp. Biol. Med., 68(10):82-5, 1969.

Cantley, M. D.; Rainsford, K. D. \& Haynes, D. R. Effects of Osteochondrin $\mathrm{S}$ and select connective tissue ribonucleinate components on human osteoclasts in vitro. J. Pharm. Pharmacol., 65(8):1214-22, 2013.

Dogini, D. B.; Pascoal, V. D.; Avansini, S. H.; Vieira, A. S.; Pereira, T. C. \& Lopes-Cendes, I. The new world of RNAs. Genet. Mol. Biol., 37(Suppl. 1):285-93, 2014.

Eftekhar-Sadat, B.; Ghavami, M.; Toopchizadeh, V. \& Ghahvechi Akbari, M. Wrist bone mineral density utility in diagnosing hip osteoporosis in postmenopausal women. Ther. Adv. Endocrinol. Metab., 7(5-6):207$11,2016$.

Haddad, P. T.; Salazar, M. \& Hernandes, L. Histomorphometry of the organic matrix of the femur in ovariectomized rats treated with sodium alendronate. Rev. Bras. Ortop., 50(1):100-4, 2015.

Jung, M. Y.; Kim, J. W.; Kim, K. Y.; Choi, S. H. \& Ku, S. K. Polycan, a bglucan from Aureobasidium pullulans SM-2001, mitigates ovariectomyinduced osteoporosis in rats. Exp. Ther. Med., 12(3):1251-62, 2016.

López-Grueso, R.; Gambini, J.; Abdelaziz, K. M.; Monleón, D.; Díaz, A.; El Alami, M.; Bonet-Costa, V.; Borrás, C. \& Viña, J. Early, but not late onset estrogen replacement therapy prevents oxidative stress and metabolic alterations caused by ovariectomy. Antioxid. Redox Signal., 20(2):236-46, 2014.

Machi, J. F.; Dias, D. da S.; Freitas, S. C.; de Moraes, O. A.; da Silva, M. B.; Cruz, P. L.; Mostarda, C.; Salemi, V. M.; Morris, M.; De Angelis, K. \& Irigoyen, M. C. Impact of aging on cardiac function in a female rat model of menopause: role of autonomic control, inflammation, and oxidative stress. Clin. Interv. Aging, 11:341-50, 2016.

Masuda, K.; Kuwano, Y.; Nishida, K. \& Rokutan, K. Application of DNA microarray technology to gerontological studies. Methods Mol. Biol., 1048:285-308, 2013.

Matsushita, H. \& Wakatsuki, A. Osteoporosis: a gender specific disease. Nihon Rinsho., 73(4):639-43, 2015.

Ni, X.; Castanares, M.; Mukherjee, A. \& Lupold, S. E. Nucleic acid aptamers: clinical applications and promising new horizons. Curr. Med. Chem., 18(27):4206-14, 2011.

Pérez-López, F. R. Postmenopausal osteoporosis and alendronate. Maturitas, 48(3):179-92, 2004.

Rainsford, K. D. Mode of Action, Uses and Side Effects of Anti-Inflammatory Drugs. In: Rainsford, K. D. (Ed.). Advances iN Anti-Rheumatic Therapy. Boca Raton, CRC Press, 1996.

Schroeder, A.; Dorn, M.; Schuehlein, K. H. \& von Sulecki, W. Die Behandlung Degenerativer Gelenkerkrankungen. Therapiewoche, 39:2310-5, 1989.

Shu, Y.; Pi, F.; Sharma, A.; Rajabi, M.; Haque, F.; Shu, D.; Leggas, M.; Evers, B. M. \& Guo, P. Stable RNA nanoparticles as potential new generation drugs for cancer therapy. Adv. Drug Deliv. Rev., 66:74-89, 2014.

Siris, E. S.; Adler, R.; Bilezikian, J.; Bolognese, M.; Dawson-Hughes, B.; Favus, M. J.; Harris, S. T.; Jan de Beur, S. M.; Khosla, S.; Lane, N. E.; Lindsay, R.; Nana, A. D.; Orwoll, E. S.; Saag, K.; Silverman, S. \& Watts, N. B. The clinical diagnosis of osteoporosis: a position statement from the National Bone Health Alliance Working Group. Osteoporos. Int., 25(5):1439-43, 2014. 
SHULGAU, Z.; SERGAZY, S.; KRIVORUCHKO, T.; KENZHEBAYEVA, N.; SAGINDYKOVA, B. \& GULYAYEV, A. Osteoprotective properties of RNA-containing drug Osteochondrin S on the model of insufficiency of sex hormones in rats. Int. J. Morphol., 35(4):1233-1238, 2017.

Stommel, G.; Schuehlein, S.; Schuehlein, K. H. \& Rainsford, K. D. Therapeutic effects of ribunucleinate (ribonucleotides) in immunoinflammatory and arthritic diseases. Prog. Drug Res., 70:35-89, 2015.

Vasconcellos, L. S.; Leite, J. M.; Sabino, K. R. \& Petroianu, A. Influence of oophorectomy on weight variance in young and adult female rats. Arq. Bras. Endocrinol. Metabol., 48(2):299-304, 2004.

Zeliadt, N. Big pharma shows signs of renewed interest in RNAi drugs. Nat. Med., 20(2):109, 2014.

Corresponding author:

Zarina Shulgau

$13 / 5$, Kurgalzhynskoye Road

Astana, 010000

KAZAKHSTAN

E-mail address: shulgau@biocenter.kz

Accepted: $15-03-2017$

Received: 03-05-2017 